\title{
Review Note: Local Government Reform and Local Government Finance
}

Commonwealth Journal of Local Governance

Issue 4: November 2009

http://epress.lib.uts.edu.au/ojs/index.php/cjlg

\section{Brian Dollery}

Centre for Local Government, University of New England Australia
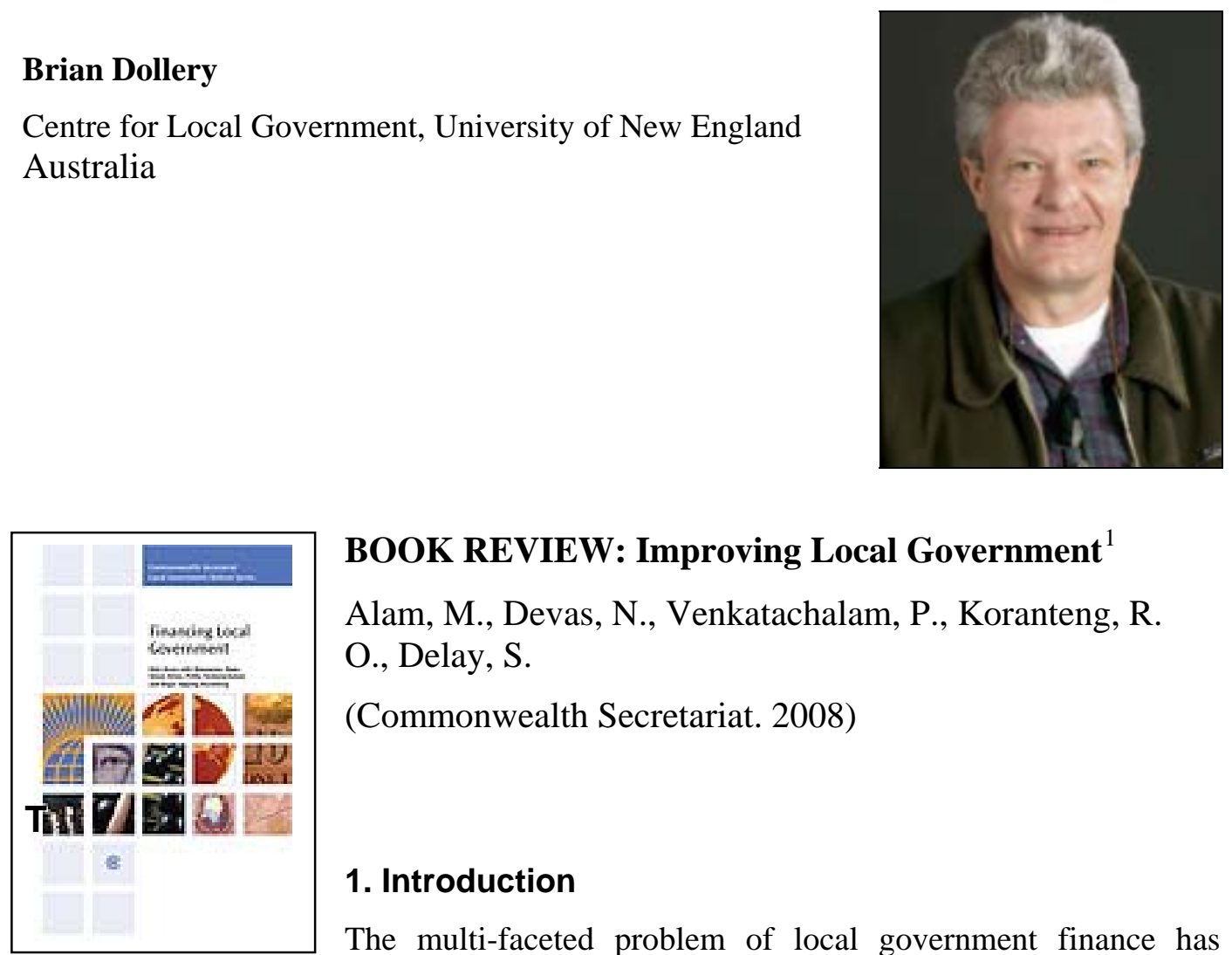

\section{BOOK REVIEW: Improving Local Government ${ }^{1}$}

Alam, M., Devas, N., Venkatachalam, P., Koranteng, R. O., Delay, S.

(Commonwealth Secretariat. 2008)

\section{Introduction}

The multi-faceted problem of local government finance has attracted increasing attention in the new millennium. The reasons for the renewed interest in this thorny question are comparatively straightforward. In the first place, for the past two decades all public sector institutions have been profoundly affected by the twin revolutions simultaneously sweeping the world - the globalization of the international economy and the information revolution wrought by the computer age - and local government is no exception. Not only have these inexorable forces had dramatic implications for the structure of government as a whole, and relationships between the different tiers of government, but also for service provision and public finance, including

\footnotetext{
${ }^{1}$ ISBN 9780850928532
} 
local public finance. Secondly, substantially heightened demands on local government, together with limited access to adequate funding, have seen the genesis of a deepening crisis in the financial sustainability of local government entities.

Although local government has almost always been a much neglected area of intellectual concern, especially compared with academic interest in higher levels of government, this time local government in general, and local public finance in particular, has attracted considerable attention from scholars. This is evident from the plethora of recent books dealing with local government finance. Perhaps the most significant contribution has come in the form of an ongoing stream of books produced in the World Bank Public Sector Governance and Accountability Series under the series editor Anwar Shah. These volumes first began appearing in 2005 with the publication of Public Services Delivery as well as Public Expenditure Analysis. Since that time a steady stream of books has emerged, all edited by Anwar Shah, including Local Governance in Industrial Countries (2006), Local Governance in Developing Countries (2006), Intergovernmental Fiscal Transfers (2006), Participatory Budgeting (2007), Budgeting and Budgeting Institutions (2007) and Macro Federalism and Local Finances (2007).

In addition to this collection of books, it is possible to identify numerous other recent noteworthy contributions in a similar vein in the local government literature. These include Boyne (1998) Public Choice Theory and Local Government, Bailey (1999) Local Government Economics, Dollery, Crase and Johnson (2006) Australian Local Government Economics, Honadle, Costa and Cigler (2004) Fiscal Health for Local Government, Garcea and LeSage (2005) Municipal Reforms in Canada, John (2001) Local Governance in Western Europe, Denters and Rose (2005) Comparing Local Governance, Freire and Stren (2001), The Challenge of Urban Government, Dollery, Garcea and LeSage (2008) Local Government Reform, Bahl and Smoke (2003), Restructuring Local Government Finance in Developing Countries, Dollery and Robotti (2008) The Theory and Practice of Local Government Reform, and Wallis, Dollery and McLoughlin (2007) Reform and Leadership in the Public Sector, amongst a host of other significant books and scholarly papers. Financing Local Government (2008) by Nick Devas and several collaborators, published by the Commonwealth Secretariat in its Local Government Reform Series, represents a recent addition to this valuable literature. This review note considers Financing Local Government in the context of contemporary 
thought on local government finance and especially local government financial sustainability.

The review note is divided into two main parts. Section 2 provides a synoptic outline of Financing Local Government in order to give the reader a brief account of the general thrust of the book. Section 3 discusses the neglected problem of financial sustainability in local government and the difficulties involved both with the concept and its application to local government. The note ends with some concluding remarks in section 4.

\section{Financing Local Government}

Financing Local Government should be seen against the background of a global trend towards decentralisation of the public sector, which has taken place in many nations, including Commonwealth countries. This trend has been driven by various economic, political and social forces, not least an attempt to address local needs and regional differences in many developed and developing nations, as well as the failure of the centralised socialist state in transition economies. As a consequence of this trend, a great deal of effort has been directed at designing efficient and equitable decentralised governmental systems. However, in almost all cases, the decentralisation of responsibility to lower tiers of government, most notably local government, has not been accompanied by a corresponding decentralisation of financial capacity. Financial sufficiency for local government requires not only additional powers to levy local taxes, but also the freedom to determine local charges, local fees and other local sources of revenue. The main consequence of the failure of national governments to decentralise fiscal capacity has been the development of a crisis in financial sustainability in many local government systems, especially rural municipalities.

While the specific reasons for the emergence of financial distress in local government systems differ between countries, as well as between the different local government jurisdictions in a given country, in general the problem can be traced back to two generic factors. In the first place, the almost universal existence of vertical fiscal imbalance in multi-tier governmental systems arises from the fact that national governments usually gather most tax income, which typically exceeds the expenditure requirements of central government agencies. The main reason for this unbalanced fiscal structure rests on the 
existence of substantial economies of scale in tax collection. But since the central government has excess revenue relative to need and lower levels are faced with the reverse, this implies a need for fiscal transfers between the different tiers of government. Three possible avenues have been employed: tax sharing, financial transfers from central and/or provincial governments, and the devolution of tax powers. It is obvious that if the magnitude of funds transferred to local government through these three methods is inadequate, then a financial problem will develop in local government if current service provision is to be maintained. This is especially relevant under circumstances where additional functions are transferred to local government without accompanying additional funding as a result of decentralisation policies.

Secondly, and in common with vertical fiscal imbalance, most systems of government also exhibit horizontal fiscal imbalance, which describes a condition in local government where different local authorities have different revenue-raising and expenditure characteristics. In short, some local governments are 'rich' and others 'poor', with small rural local governments often falling into the latter category. This has invidious equity implications for local service provision to local communities. In many local government jurisdictions, the problems posed by horizontal fiscal imbalance are addressed to various degrees by means of fiscal transfers. Nonetheless, it is obvious that under decentralisation the quantum of horizontal fiscal imbalance will intensify and thereby exacerbate disparities between different local authorities.

Against this background, both practitioners and scholars will find Financing Local Government, part of an ongoing Commonwealth Secretariat Local Government Reform Series, a useful addition to the literature on local government finance outlined earlier. The book itself comprises an Introduction by Munawwar Alam, the Series Editor, followed by twelve chapters on different dimensions of local government finance. The administrative and financial implications of financial decentralisation in local government represent the general theme that connects most of these chapters. A second appealing feature of Financing Local Government resides in its practical orientation. This is likely to appeal to practitioners in local government who deal directly with formulating and administrating financial policy in their local authorities. 
Chapter 1 by Nick Devas considers trends in decentralisation, the reasons for these trends and the arguments for and against decentralisation in local government. Devas contends that fiscal decentralisation must be accompanied by carefully attuned local taxes, scope for local fees and charges, regulations for local government-owned businesses, and borrowing by local governments. In addition, functional responsibilities should be clearly defined. Chapter 2 explores local government revenue in more detail, by summarising the different sources of revenue available to local government, as well as their strengths and weaknesses. Chapter 3 continues discussion of this terrain by tackling the problem of local revenue administration and how best to design efficient revenue administration systems.

Chapter 4 deals with the financing of capital investment by local government. Borrowing is considered in detail as well as other sources of capital investment funds. In Chapter 5, Pritha Venkatachalam extends this discussion by focusing on various innovative methods of financing local government infrastructure adopted in Tamil Nadu.

Chapter 6 moves outside 'own-source' revenue and tackles the question of intergovernmental transfers. The full range of transfers from central government to subnational and local governments is considered, which includes tax/revenue sharing arrangements, general (block) grants, specific grants, deficit grants, capitalisation grants and subsidised loans. Chapter 7 focuses on budgeting and expenditure management in local government. It discusses setting expenditure priorities, financial planning, and financial control. Chapter 8 extends this discussion by dealing with accounting and auditing in local government, using British illustrative examples. Chapter 9 completes this section of Financing Local Government by outlining citizen participation in budgetary processes and local government accountability.

The final part of Financing Local Government consists of two 'case studies' and a concluding Chapter 12. Chapter 10 looks at local government finance in England whereas Chapter 11 considers fiscal decentralisation in Ghana.

The arrangement of material in Financing Local Government is confusing. Although financial constraints impinge on all local government systems, the nature of these constraints differs widely and alternative policy remediation options exist. However, a 
basic distinction must be drawn between developed and developing countries, mostly because local government systems in poor nations have more acute capacity limitations, notably administrative and technical incapacity. Unfortunately, this distinction is barely drawn in Financing Local Government, which considers both advanced country experience, such as English local government finance in Chapter 10, as well as practice in poor nations, like Ghanaian fiscal decentralisation in Chapter 11. It would have been better had Financing Local Government been split into different parts dealing with developed and developing countries separately.

\section{Financial Sustainability in Local Government}

A more serious deficiency with Financing Local Government, which it has in common with almost all the other contemporary literature on local government reform and local government finance, concerns its neglect of the crucial concept of financial sustainability in local government.

In most local government jurisdictions in rich and poor countries alike, central and/or provincial governments periodically assess the financial circumstances of the local authorities in their local government systems. If this process exposes financial distress in particular municipalities, then this can lead to intervention by central and/or state government agencies. Financial oversight by state government agencies of local councils is a thorny question because it inevitably involves developing methods of assessing the financial performance of local authorities. The conceptual and empirical difficulties involved in formulating and implementing accurate financial performance measurement systems are formidable.

Various factors account for these difficulties. Firstly, despite numerous attempts to conceptualise the problem, concisely summarised by Honadle, Costa and Cigler (2004) in Fiscal Health for Local Governments, there is no agreed definition of what constitutes 'financial sustainability' over the long term in local government. In this regard, Honadle, Costa and Cigler (2004, p. 18) have noted that there is not even 'consensus about the terminology surrounding fiscal health'. Numerous conflicting definitions exist in the literature. For instance, in the fiscal analysis of American local government, scholars have proposed a bewildering array of terms, including 'fiscal health' (Berry1994), ‘financial condition’ (Lin and Raman 1998), ‘fiscal strain’ (Clark and Appleton 1989), 
'fiscal stress' (Pagano and Moore 1985), 'fiscal capacity' (Johnson and Roswick 1991), and 'fiscal crisis' (Campbell 1991). By contrast, in Australia the term 'financial sustainability' has recently acquired almost universal acceptance, despite the fact that it lacks concrete meaning in Australian policy discourse.

One can readily understand how conceptual difficulties of this kind have arisen in the financial analysis of local government. For example, should financial health refer to short term or long run time periods? Similarly, how long should time horizons be? In an analogous vein, should the financial circumstances of a given council be judged exclusively in the light of financial magnitudes, such as operating expenditure, operating revenue, indebtedness, and the like, or should the yardstick reside in standards of service provision and community expectations? After all, cynics have often pointed out that a local council can easily improve its fiscal standing by simply reducing or eliminating service provision! Put differently, should financial performance in local government be assessed in its own terms or relative to operational effectiveness in service provision? What weight should be accorded to operational efficiency that can be determined by management compared with external factors beyond the control of local authorities?

Secondly, quite apart from the difficulties involved in developing a satisfactory definition of financial distress in local government, further unresolved problems exist in adequately measuring financial performance. For instance, the first attempt at systematically evaluating the fiscal standing of local government was undertaken by the American Advisory Commission on Intergovernmental Relations (ACIR) in 1973 which devised six early 'warning signs' of 'local financial emergencies' in the form of financial indicators. This engendered a rapidly growing literature on the development of performance indicators for local government in the United States (see, for example, Kloha, Weissert and Kleine 2005), which culminated in the construction of comparative indicators, typically in the form of financial ratios (see, for instance, Brown 1993; 1996).

Parallel developments have occurred in various other national contexts. For example, Australian local government has recently witnessed a series of state and national inquiries into local government that have sought to find the 'holy grail' of an operational definition of financial sustainability in local government. Thus the methodologies developed in the South Australian Financial Sustainability Review Board's (2005) Rising 
to the Challenge, the Financial Sustainability of NSW Local Government's (2006) Are Councils Sustainable, and the Queensland Local Government Association's (2006) Size, Shape and Sustainability all attempted to define financial sustainability and develop attendant comparative measures of local government financial performance.

The aim of these exercises in constructing comparative indicators that can be applied to a whole local government system is certainly laudable. Policy makers seek some kind of 'objective' measurement tool that will enable them to compare the performance of individual local authorities and make recommendations that are unbiased. However, in the Australian context at least, this approach has been flawed. In this regard, Woodbury, Dollery and Prasada Rao (2003, p. 78) have argued that in Australian local government 'performance has been exclusively assessed by either comparing performance indicators against data for similar councils, primarily the "average council” figure for that state, or by comparing current performance with earlier indicators for a given council'. The problem is that "little effort has been directed at explaining why there are differences between councils, determining what constitutes "best practice" levels of efficiency, or how state governments can best apply direct pressure to force inefficient councils to improve performance'.

Kloha, Weissert and Kleine (2005, pp. 316-317) have identified some of the general problems inherent in all system-wide local government comparative financial indicators. Firstly, almost all indexes of comparative indicators contain 'too many variables' that limit the 'ability to assess which are the most important or to combine them into a more useable and easily understood composite'. Secondly, the 'exclusion of key variables' consequent upon 'focusing almost exclusively on balance sheet data seems to hinder an indicator's ability to give early warning of distress.' An additional problem resides in 'ambiguous expectations' since 'some indicators include variables that may have differing interpretations'. A 'failure to allow for diverse preferences' typically derives from the application of average financial ratio values to every local council in strident defiance of preference differences on the part of residents of different local authorities. In the fifth place, an emphasis on the 'relative rather than absolute' values of indicators serves to punish councils whose absolute values are satisfactory but that fall at the end of a scale. An inability 'to focus on one locality' is a further problem that plagues systems of comparative indicators since 'ratios for all local governments must be computed 
before the relative fiscal health of a single government can be determined' with onerous cost implications. Finally, acquiring accurate data is always a problem.

These specific problems inherent in almost all sets of local government financial performance indicators are amplified when we consider wider conceptual anomalies. For instance, in The Financial Analysis of Governments, Berne and Schramm (1986, p. 93) stress that 'the judgment factor will never be replaced entirely by cookbook formulae' offered by the apparent 'objectivity' of quantitative financial ratios in comparative local government performance indicators. Similarly, in direct reference to Australian performance indicators, Worthington and Dollery (2000) emphasised the significance of 'nondiscretionary variables' in performance indicators that cannot be altered by the behaviour of a given council. Nondiscretionary variables include items such as pensioner rate rebates, non-rateable properties in a local government area, the proportion of nonEnglish speaking and Aboriginal people, and a host of economic and social factors that cannot be influenced by a council.

\section{Concluding Remarks}

In this review note, we have considered the literature on local government finance, placed Financing Local Government in this context, and then demonstrated that the problem of defining financial sustainability in local government is unresolved and the application of this concept to local authorities in the form of various financial indicators is flawed. We have argued that the literature on local government finance is deficient in the sense that it often ignores this problem. Financing Local Government shares this problem with comparable books published over the past decade.

While Financing Local Government represents a useful addition to the literature on local government finance, especially in terms of its accessibility to practitioners in local government, it does not provide the reader with a complete picture because it has neglected the question of financial sustainability. This is a pity since a significant proportion of contemporary local government policy making is devoted to financially unsustainable local authorities. 


\section{References:}

Advisory Commission on Intergovernmental Relations 1973, City Financial Emergencies: The Intergovernmental Dimension, Government Printing Office, Washington.

Bahl, R and Smoke, P 2003, Restructuring Local Government Finance in Developing Countries. Lessons from South Africa, Edward Elgar, Cheltenham.

Bailey, S J 1999, Local Government Economics. Principles and Practice, Macmillan, London.

Berne, R and Schramm, R 1986, The Fiscal Analysis of Government, Prentice-Hall, Englewood Cliffs.

Berry, F S 1994, 'Innovation in Public Management: The Adoption of Strategic Planning', Public Administration Review, 54(2), pp. 322-330.

Boyne, G A 1998, Public Choice Theory and Local Government: A Comparative Analysis of the UK and the USA. Macmillan, London.

Brown, K W 1993, 'The 10-Point Test of Financial Condition: Toward an Easy-to-Use Assessment Tool for Smaller Cities’, Government Finance Review, 9(6), pp. 21-26.

Brown, K W 1996, 'Trends in Key Ratios Using the GFOA Financial Indicators Database 19891993’, Government Finance Review, 12(6), pp. 30-34.

Campbell, A K (ed.) 1991, The States and Urban Crisis, Columbia University Press, New York.

Clark, T and Appleton, L 1989, 'Coping in American Cities’, in S. Clarke (ed.), Urban Innovation and Autonomy, Sage, Newberry Park.

Denters, B and Rose, L (eds.) 2005, Comparing Local Governance. Trends and Developments. Palgrave McMillan, London.

Devas, N with Alam, M, Delay, S, Vankatachalam, P and Korateng, R O 2008, Financing Local Government. Commonwealth Secretariat Local Government Reform Series, Commonwealth Secretariat, London.

Dollery, B E Crase, L and Johnson, A 2006, Australian Local Government Economics, University of New South Wales Press, Sydney.

Dollery, B E and Robotti, L (eds.) 2008, The Theory and Practice of Local Government Reform, Edward Elgar, Cheltenham.

Dollery, B E Garcea, J and LeSage, E (eds.) 2008, Local Government Reform: A Comparative Analysis of Advanced Anglo-American Countries, Cheltenham, Edward Elgar.

Freire, M and Stren, R E 2001, The Challenge of Urban Government. Policies and Practices, University of Toronto Centre for Urban and Community Studies.

Garcea, J and LeSage, E (eds) 2005, Municipal Reforms in Canada, Oxford University Press, Toronto.

Garcea, J and LeSage, E C Jr (eds) 2005, Municipal Reforms in Canada, OUP.

Honadle, B W, Costa, J M and Cigler, B A 2004, Fiscal Health for Local Governments, Elsevier, New York.

Independent Inquiry into Local Government Inquiry (LGI) 2006, Are Councils Sustainable? Final Report: Findings and Recommendations, NSW Local Government and Shires Association, Sydney.

John, P 2001, Local Governance in Western Europe, Sage Publications, London.

Johnson, F A and Roswick, D L 1991, ‘Local Fiscal Capacity’, in JE. Peterson and D.R. Strachota (eds.), Local Government Finance: Concepts and Practices, Government Finance Association, Chicago.

Koha, P, Weissert, C S and Kleine, R 2005, 'Developing and Testing a Composite Model to Predict Local Fiscal Distress’, Public Administration Review, 65(3), pp. 313-323. 
Lin, W and Raman, K K 1998, 'The Housing Value Relevance of Governmental Accounting Information', Journal of Accounting and Public Policy, 17(2), pp. 91-118.

Local Government Association of Queensland Inc 2004, Size, Shape and Sustainability of Queensland Local Government, Discussion Paper, Local Government Association of Queensland, Brisbane.

Local Government Association of Queensland Inc 2006, Size, Shape and Sustainability: Guidelines Kit, Local Government Association of Queensland, Brisbane.

Pagano, M and Moore, R J T 1985, Cities and Fiscal Choices: A New Model of Urban Public Investment, Duke University Press, Durham.

Sancton, A 2000, Merger Mania, McGill-Queen’s University Press, Montreal.

Shah, A (ed.) 2005, Public Expenditure Analysis, World Bank, Washington.

Shah, A (ed.) 2005, Public Services Delivery, World Bank, Washington.

Shah, A (ed.) 2006, Intergovernmental Fiscal Transfers. Principles and Practice, World Bank, Washington.

Shah, A (ed.) 2006, Local Governance in Developing Countries, World Bank, Washington.

Shah, A (ed.) 2006, Local Governance in Industrial Countries, World Bank, Washington.

Shah, A (ed.) 2007, Budgeting and Budgeting Institutions, World Bank, Washington.

Shah, A (ed.) 2007, Participatory Budgeting, World Bank, Washington.

Shah, A (ed.) 2008, Macro Federalism and Local Finances, World Bank, Washington.

Wallis, J L, Dollery, B E and McLoughlin, L 2007, Reform and Leadership in the Public Sector: A Political Economy Approach, Edward Elgar, Cheltenham.

Woodbury, K, Dollery, B E and Prasada Rao 2003, 'Is Local Government Efficiency Measurement in Australia Adequate? An Analysis of the Evidence', Public Productivity and Management Review, 27(2), pp. 77-91.

Worthington, A C and Dollery, B E 2000, 'Measuring Efficiency in Local Government's Planning and Regulation Function', Public Productivity and Management Review, 23(4), pp.469-485. 